\section{THE BRITISH INSTRUMENT INDUSTRIES' EXHIBITION}

$\mathrm{T}$

HE second exhibition of the British Instrument Industries was held during June 30-July 11 in the National Hall, Olympia, London, two years after the first. It is the intention of the sponsors-five trade associations concerned wholly or partly with instrument manufacture-and organizers to make the exhibition a biennial event.

The confidence in the value of the exhibition shown by these plans seems to be justificd: the second exhibition had more exhibitors than the first; the exhibitors, numbering 168 , represented adequately the British instrument industries and included most of the large firms and many of the smaller ones; and the products displayed (of $414 \mathrm{kinds}$, according to a count of the subject headings of the classified index in the catalogue) were representative of the scientific and industrial instruments made in Great Britain. The hall, which was well set out, appeared to be comfortably filled and the exhibitors busy.

The instruments on show, too numerous to be described individually, revealed one general and wellrecognized trend and several local and less obvious ones. The general one is, of course, the increasing extent to which almost every type of modern instrument incorporates, and is dependent upon, electrical or electronic components or accessories, which are therefore expected to be almost as reliable and trouble-free as the cases and stands themselves.

Apart from this general trend, some small but probably significant changes are discernible. Thus there appears to be an increasing number of instruments made for non-destructive testing, and particularly for thickness gauging, with special emphasis on the measurement of the thickness of electrodeposits and coats of paint. The application of radioactivity is becoming more common and new uses are being found: one exhibit was an ionization anemometer, where the rate at which air ionized by a radioactive source is blown away provides a measure of wind velocity. Strain gauges are becoming ubiquitous research tools, and are taking on new forms, incorporated, for example, in compact, hermetically sealed load cells.

Some of the exhibits provided encouraging evidence that there is not always as long a delay in developing commercial models of instruments from the products of the research laboratories as is often supposed. The flying-spot microscope, the possibilities of which were pointed out by Roberts and Young as recently as 1951 (Nature, 167, 231 ; 1951), was on show (not for the first time) and was no longer regarded by visitors as a novelty. Recent work on the production of transparent conducting coatings on glass for de-icing instrument windows or preventing static charges from building up on them has already borne fruit in commercially available indium, cadmium oxide, and gold coatings on glass squares with light transmissions up to 90 per cent (indium) and resistances from 5,000 (indium) down to 15 (gold) ohms. This augurs well for the prospects of early development of commercial models of some of the useful prototype instruments -a simple radiometer, a capacitance-resistance hygrometer, and a voltage stabilizer, to mention three-shown on the stand of the Department of Scientific and Industrial Research by some of its establishments and the research associations.
The exhibition has brought to mind three matters which might well be given further consideration before the next one is held. First, is the word 'Celsius' to be used instead of 'Centigrade' in accordance with the International Temperature Scale adopted internationally in 1948? Many exhibitors marked their instruments ' ${ }^{\circ} \mathrm{C}$. '; but of those who used a complete word, only one was noticed to have employed 'Celsius'. Second, are the results of the recent work by the Naval Motion Study Unit and others on the design of dials and indicators generally applicable? Third, can substantial effort be devoted to finding means of reducing reflexion from instrument windows? With the prevalence of rows of panel-mounted instruments observed by one man who sees each instrument from a different angle and cannot, therefore, avoid reflexions from all of them by moving his head, this trouble has become serious.

\section{O BITUARY}

\section{Dr. Tom Goodey, O.B.E., F.R.S.}

Dr. Tom Goodey, who died suddenly on the evening of July 7 on his way home from a Friends' meeting, was born at Wellingborough on July 28, 1885. $\mathrm{He}$ was educated at the County School, Northampton, and at the University of Birmingham, where he took the degrees of B.Sc. (with honours in zoology and botany) in 1908, M.Sc. in 1909 and D.Sc. in 1915 . In 1910 he was elected to the Mackinnon Studentship of the Royal Society. During the year 1912-13 he was protozoologist at Rothamsted Experimental Station and returned there in 1920 after serving during 1913-19 on the staff of the laboratory of agricultural zoology attached to the Department of Zoology at the University of Birmingham. In 1921 he was transferred by the Ministry of Agriculture to the agricultural section which the Ministry subsidized in the Department of Helminthology at the London School of Tropiaal Medicine. When this Institution became incorporated in the new London School of Hygiene and Tropical Medicine, the Development Commission provided the School with a field station, for the work on agricultural helminthology, at Winches Farm, St. Albans, which later became generally known under the title of Institute of Agricultural Parasitology. There Goodey worked from 1926 until 1947 and ultimatcly became a principal scientific officer. On the retirement of its director, those members of the staff who were engaged on rosearch into plant-parasitic nematodes were transferred by the Ministry of Agriculture to Rothamsted, and Goodey became head of the new Nematology Department there. Although he retired from this position last year, he continued to take an active share in the work of the Department up to the day of his death.

Goodey's earlier researches were mainly concerned with the activitios of Protozoa in the soil ; but the investigations by which he acquired an international reputation were those on the nematodes parasitic in and on plants, and the related forms present in soil and fresh water. In 1933 he published "PlantParasitic Nematodes and the Diseases they Cause". This was followed in 1951 by "Soil and Freshwater Nematodes"- the first comprehensive monograph on this subject in the English language.

All his scientific writings were characterized by a clarity and felicity of expression and illustrated by a 